研究

\title{
バイオ用途への応用を目的とした磁性アミロースビーズの開発
}

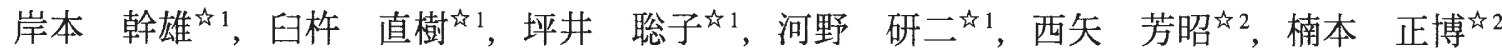 \\ 的1日立マクセル 開発本部, $=618-8525$ 京都府乙訓郡大山崎町小泉 1. \\ 的東洋紡績 敦賀バイオ研究所, $=914-0047$ 敦賀市東洋町 10-24.
}

\section{Development of Magnetic Amylose Beads for Biological Application}

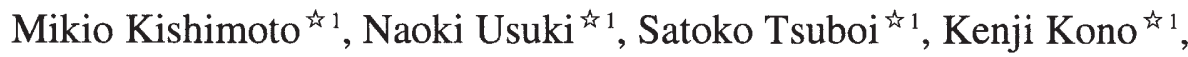 \\ Yoshiaki Nishiya ${ }^{\text {it } 2}$ and Masahiro Kusumoto ${ }^{\text {is } 2}$ \\ ${ }_{4}^{\text {It }}$ Hitachi Maxell, Ltd., 1 Koizumi, Ohyamazaki-cho, Otokuni-gun, Kyoto 618-8525, Japan. \\ ${ }^{2}$ Toyobo Co., Ltd., 10-24 Toyo-cho, Tsuruga 914-0047, Japan.
}

Received February 20, 2007

\begin{abstract}
SYNOPSIS
Magnetic beads were developed for the purpose of applying to biological use. The beads were composed of magnetite particles coated with amylose which showed the affinity bonding with maltose binding protein. The beads showed superior response to magnetic field based on the high magnetization and superior dispersability after the removal of magnetic field in the process of purifying a protein from biological samples. The beads showed five times greater efficiency in purification of protein than amylose resin beads currently on the market.
\end{abstract}

KEY WORDS

magnetic beads, magnetite particles, amylose, maltose, protein

\section{1 緒 言}

磁性粒子は外部磁界により迅速に分離回収や誘導ができる ため, バイオテクノロジーの分野で広く研究され，既に磁性 粒子を無機あるいは有機化合物で修飾した各種の磁性ビーズ が実用化されている ${ }^{1-4)}$. 特に，磁性粒子にシリカの被膜を形 成した粒子サイズが $5 \mu \mathrm{m}$ 程度の磁性シリカビーズは, 外部磁 界によりサンプル液中で容易に磁性ビーズだけを分離捕集で きるため，自動化に適した核酸抽出用の磁性ビーズとして広 く使用されている ${ }^{5,6)}$. 磁性ビーズを用いた生体物質の抽出精 製において，通常粒子サイズが小さくなるほど表面積が大き くなるため, 精製効率は向上する. しかし微粒子化により磁 化が小さくなるため磁界による捕集性が低下し，操作性が悪 くなる問題がある。

最近では表面修飾磁性ビーズの用途として,タンパク質精 製を自動化してハイスループット化する用途への展開が期待 されている。しかしタンパク質精製を目的とした磁性ビーズ としては, His-tag 融合タンパク質用磁性ビーズ以外，ほとん ぞ実用化されていないのが現状である7).

筆者らは，効率よくタンパク質を精製できる磁性ビーズの 実用化を目的に, 約 $200 \mathrm{~nm}$ のサイズの球状のマグネタイト粒
子の表面にアミロースを被着させた磁性アミロースビーズを 開発した。この磁性アミロースビーズは，マルトース結合夕 ンパク質(MBP)がアミロースに特異的に結合することを利用 したものであり，この磁性アミロースビーズにより MBPを効 率よく抽出精製できることを確認した。

本報では, 磁性アミロースビーズの合成方法と, 磁界捕 集性およびタンパク質抽出精製能について調べた結果を報告 する.

\section{2 実験方法}

磁性アミロースビーズの原料となる酸化鉄粒子は，以下に 示す鉄塩の水溶液中の酸化反応により合成した. 硫酸第一鉄 $\left(\mathrm{FeSO}_{4} \cdot 6 \mathrm{H}_{2} \mathrm{O}\right)$ を溶解した $\mathrm{Fe}^{2+}$ の水溶液を䚓挥しながら $\mathrm{NaOH}$ 水溶液を滴下して水酸化第一鉄を析出させた．この水酸化第 一鉄の懸濁液の $\mathrm{pH}$ を 9〜10に調整して，懸濁液の温度を約 $80^{\circ} \mathrm{C}$ に維持して, 空気酸化により酸化鉄粒子を作製した.こ の酸化鉄粒子は, $\mathrm{X}$ 線回折により $\mathrm{Fe}_{3} \mathrm{O}_{4}$ の構造を有するマグネ タイト粒子であることを確認した。ママグネタイト粒子のサイ ズは, $\mathrm{pH}$ や温度, 酸化条件により変化するが, 本報告では, 平均粒子サイズが約 $200 \mathrm{~nm}$ のマグネタイト粒子を用いて磁性 
アミロースビーズを合成した結果について述べる.

アミロースとしては市販品を使用し，このマグネタイト粒 子の表面に被着させた. まず超音波分散機を用いてマグネタ イト粒子の水分散体を作製した．アミロースは，熱水には溶 解するが室温ではほとんど溶解しないことが知られている. そこでこの温度によるアミロースの溶解量の差異を利用して マグネタイト粒子表面にアミロースを析出させた．まず予備 実験として，本検討に用いたアミロースに水を加え，䚓汼し ながら $90^{\circ} \mathrm{C}$ に加熱するとほぼ透明液となり，この液を室温ま で泠却するとほぼ全量が析出することを確認した。 そこでマ グネタイト粒子の水分散液に所定量のアミロースを添加し, 摫汼しながら $90^{\circ} \mathrm{C} て ゙ 1$ 時間加熱し, その後 1 時間かけて $25^{\circ} \mathrm{C}$ まで徐冷することにより, マグネタイト粒子表面にアミロー スを析出させた.

水洗, ろ過, 乾燥後, マグネタイト粒子の表面にアミロー 又を強固に被着させるため, 加熱処理を行った. その際, ア ミロースの構造を変化させないように，アミロースの構造変 化を調べながら雾囲気と温度を調整し, 加熱処理条件を窒素 ガス中, $60^{\circ} \mathrm{C}$ で 2 時間加熱とした.

このようにして合成した磁性アミロースビーズは，その後 の溶液反応においてアミロースが脱落することがなく, マグ ネタイトの表面に強固に被着していることを確認している.

マグネタイト粒子へのアミロースの被着の確認は, FTIRを 用いて行った.アミロースビーズの磁界中での捕集性は, ビーズの分散液に磁界を印加したときの吸光度の時間変化か ら調べた. またアミロースビーズの MBP融合タンパク質の精 製能は, MBP融合タンパク質の発現プラスミドを導入した培 盖大腸菌の破砕液に磁性アミロースビーズを加えてMBP融合 タンパク質を抽出し，その抽出量を電気泳動法により調べた.

\section{3 実験結果及び考察}

3.1 磁性アミロースビーズの構造

Fig.1にアミロースをマグネタイトに対して1wt\%添加し，上 述した方法によりマグネタイト粒子の表面にアミロースを被 着させた磁性アミロースビーズのSEM写真を示す. 粒子はサ イズが約 $200 \mathrm{~nm}$ で, ほぼ球状形状を有している.アミロース

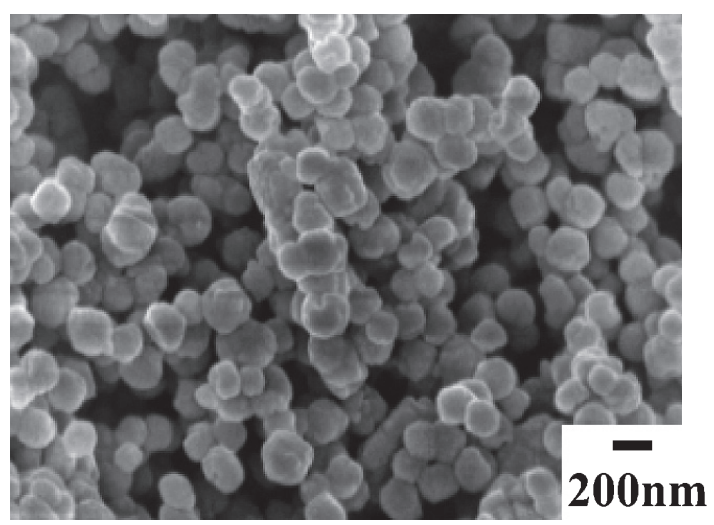

Fig.1 SEM photograph of magnetic amylose beads.
は微量であるためSEM写真からは観察されず, 原料となるマ グネタイト粒子とほぼ同一形状を示す。

Fig.1に示す磁性アミロースビーズについて FTIR 解析を 行った. Fig.2(a)に, アミロースのFTIRスペクトルを示す.ま た合成したマグネタイト粒子と磁性アミロースビーズについ てもFTIR測定を行った. Fig.2 (b)に, この磁性アミロースビー ズとマグネタイト粒子との FTIR の差スペクトルを示す. 900 〜 $1200 \mathrm{~cm}^{-1}$ に存在するC-O吸収は多少のシフトはあるが, ほ ぼ一致している.

アミロースは, Fig.3に示すように多数のグルコースがグリ コシド結合により重合し，直鎖状になった高分子である. Fig.2 (b)の差スペクトルにおいて, アミロースの特長的な吸収 ピークである $900 \sim 1200 \mathrm{~cm}^{-1}$ の吸収ピーク位置が, 元のアミ ロースの吸収ピーク位置とほぼ一致していることから, アミ
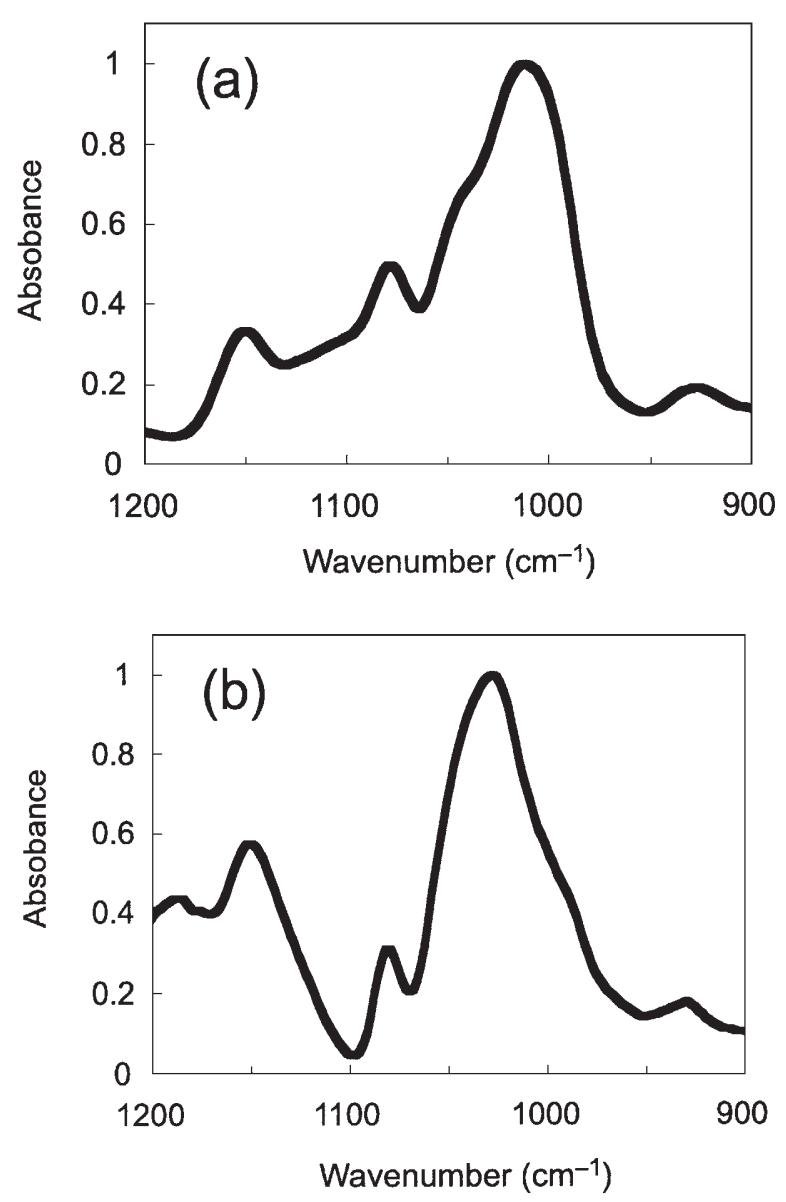

Fig.2 (a) FTIR spectrum of amylose and (b) differential spectrum of magnetic amylose beads and magnetite particles.

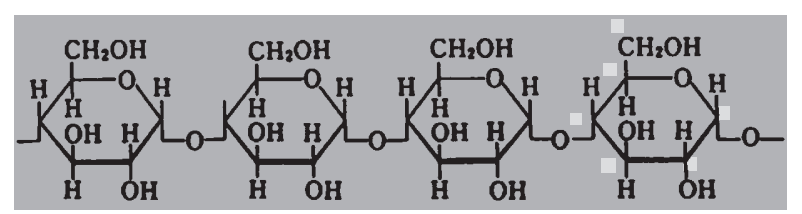

Fig.3 Structure of amylose. 
ロースはFig.3の構造を維持した状態でマグネタイト粒子に被 着していると考えられる.ビーズ上でのアミロースの結合状 態は不明であるが, アミロースとマグネタイト粒子表面のOH 基間での結合と考えられる.

原料に用いたマグネタイト粒子と，このマグネタイトに対 してアミロースを $1 \mathrm{wt} \%$ 被着させた磁性アミロースビーズの保 磁力は $80 \mathrm{Oe}$ で, 飽和磁化は $81.8 \mathrm{emu} / \mathrm{g}$ であった.

3.2 磁性アミロースの磁界による捕集

磁性アミロースビーズの磁界による捕集性を調べた．濃度 が1wt\%になるように水に磁性アミロースビーズを入れ, 超音 波分散機により磁性アミロースビーズの水分散体を作製した. 次にこの分散体を一辺が $10 \mathrm{~mm}$ の正方形で高さが $30 \mathrm{~mm}$ のガ ラス製の吸光セルに入れ, セル側面に表面磁界が約 $3000 \mathrm{Oe}$ の 磁石を接触させた．セルに波長が $555 \mathrm{~nm}$ の光を照射し，磁性 アミロースビーズの捕集に伴う吸光度の時間変化を調べた. 結果をFig.4に示す. 磁石の磁界により磁性アミロースビーズ が捕集される結果, 約 10 秒で分散液はほぼ透明になった。比 較のために，市販の核酸精製用の磁性シリカビーズの捕集性 も示す。この磁性シリカビーズは，酸化鉄粒子をシリカの被 膜でカプセル化した粒子サイズが約 $5 \mu \mathrm{m}$ の球状粒子である.

磁性アミロースビーズは, 粒子サイズが約 $200 \mathrm{~nm}$ と小さい にもかかわらず, $5 \mu \mathrm{m}$ のシリカ磁性ビーズと同等の磁界捕集 性を示す．これはシリカビーズの飽和磁化が約 $25 \mathrm{emu} / \mathrm{g}$ であ るのに対して，磁性アミロースビーズが約 $82 \mathrm{emu} / \mathrm{g}$ と大きい 飽和磁化を有するためである。.また磁界捕集後の磁性アミ ロースビーズの再分散性については，以下の方法で調べた。

磁石を引き離した後の磁性アミロースビーズは凝集してい るため，ボルティクミキサー(振動回転式䚌挥装置)で数分間 振動分散させた. 次に, 分散直後の吸光度を上述した方法と 同じ方法で調べた，その結果，吸光度は磁界印加前とほぼ同 じ値を示し，再分散処理により初期の分散状態に戻ることを

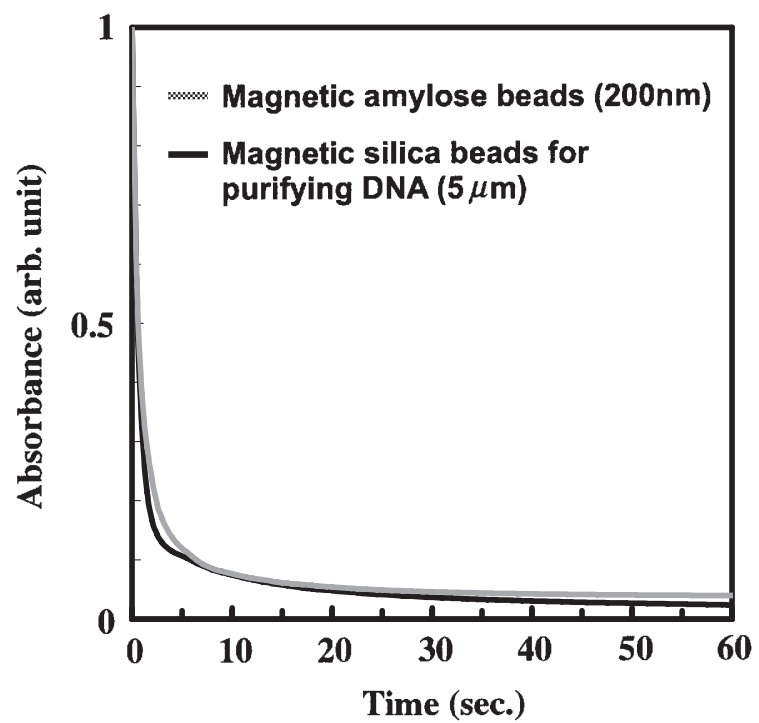

Fig.4 Response to a magnetic field of magnetic amylose beads and magnetic silica beads.
確認した.

以上の結果より, 磁性アミロースビーズ表面に結合させた タンパク質を溶離させる上で, 問題のないレベルの再分散性 を示すことがわかった．これは飽和磁化は大きいが保磁力が 80 Oeと小さいため, 磁界を印加しない状態では磁気凝集力が 小さく，容易に再分散するためと考えられる.

3.3 磁性アミロースビーズによるタンパク質精製

磁性アミロースビーズを用いて，マルトース結合タンパク 質 (MBP) がアミロースに特異的に結合することを利用して， MBP融合用ベクターを用いて大腸菌などで発現させた目的夕 ンパク質を簡便に精製できることを見出した.

Fig.5に原理図と精製プロセスを示す．まず目的の MBP 融 合タンパク質を含む溶液に磁性アミロースビーズを添加し， MBPを磁性アミロースビーズのアミロースに結合させる．こ の磁性アミロースビーズとMBP融合タンパク質の複合体を磁 界により捕集した後，不要な成分を除去する．捕集した磁性 アミロースビーズを洗浄液中で再分散および捕集を数回繰り 返し洗浄する. 最後にマルトースを含む溶液を用いて磁性ア ミロースビーズからMBP融合タンパク質を溶出させ, 目的夕 ンパク質を精製することができる. MBP 融合タンパク質は, グルコースがグリコシド結合したアミロースの先端部分に特 異的に結合していると考えられる. 磁性アミロースを用いた タンパク質の精製は，アミロースに特異的に結合したMBP融 合タンパク質を高濃度のマルトース溶液中に分散させると， アミロースはマルトースとの結合を優先し, MBP融合タンパ ク質がアミロースビーズから溶離しやすくなることを利用す るものである.

MBP融合タンパク質の精製能を以下の方法で調べた。まず MBP 融合タンパク質の発現プラスミドを大腸菌に導入した. この大腸菌を培養し, MBP融合タンパク質を発現させた. 次 に発現したMBP融合タンパク質を含む大腸菌破砕液に磁性ア ミロースビーズを加え, Fig.5に示した方法により, 菌体破砕 サンプルから MBP融合タンパク質を抽出精製した。

抽出したMBP融合タンパク質を電気泳動により調べた結果 をFig.6に示す. 比較のために，アミロースを結合させた非磁 性レジンビーズを用いた結果も示す．この非磁性レジンビー ズとして，NEB 社製のアミロースレジンビーズを使用した。 なお非磁性レジンビーズは, 磁性アミロースビーズに対して

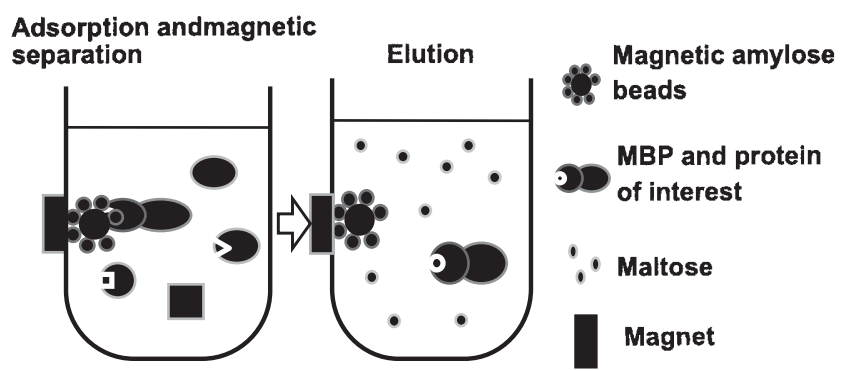

Fig.5 Principle and process for the purification of maltose binding protein (MBP) using magnetic amylose beads. 


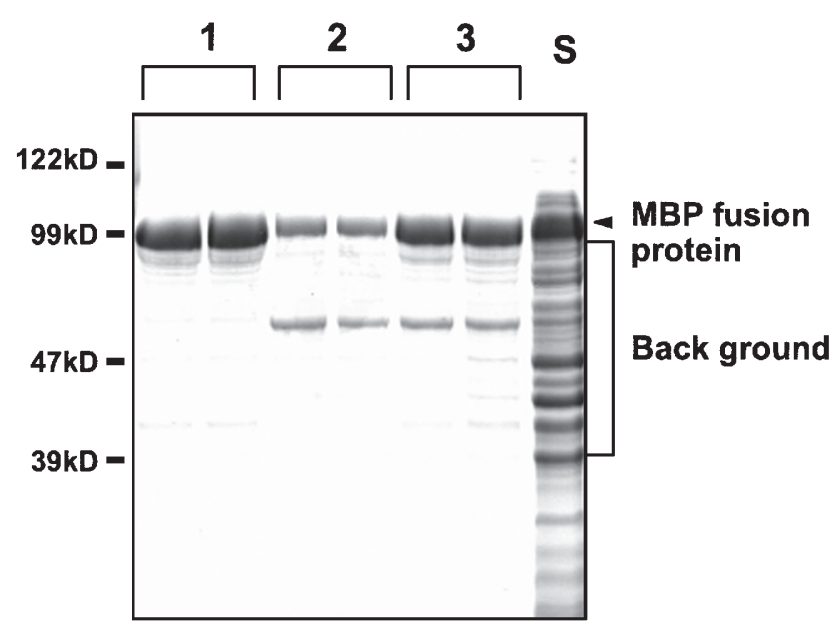

1: Magnetic amylose beads

2: Amylose resin beads

(Same quantity to magnetic amylose beads )

3: Amylose resin beads

(Five times quantity to magnetic amylose beads)

\section{4: Cell extract (supernatant)}

Fig.6 Results of analysis of electrophoresis of maltose bonding protein (MBP) purified by using magnetic amylose beads and amylose resin beads. The bandwidth shows the quantity of purified MBP.

同量および 5 倍の重量を用いて調べた。電気泳動によるバン ド幅が目的タンパク質の精製量を示しており, 磁性アミロー スビーズは，非磁性レジンビーズを 5 倍の重量を使用したも のと同等の精製量を示し，非磁性レジンビーズに比べて優れ た抽出精製能を有することがわかる.また，宿主MBP由来の バックグラウンドが見られず, 純度の高い精製タンパク質が 得られることを示している.

この磁性アミロースビーズの優れたMBP融合タンパク質精 製能は，非磁性レジンビーズの粒子サイズが約 $100 \mu \mathrm{m}$ と大き いのに対して，磁性アミロースビーズの粒子サイズが約 200 $\mathrm{nm}$ と小さいことによる. 磁性アミロースビーズは微粒子のた め表面積が大きく,アミロースとMBPの結合サイトが多くな るためと考えられる. 非磁性レジンビーズは, 通常ガラスや プラスチック製のカラムに充填して洗浄液を流してMBP融合 タンパク質を分離捕集するため, 微粒子になると洗浄液が流 れにくくなり，操作性が悪くなるため本質的に微粒子化が困 難である。一方磁性アミロースビーズは磁界を利用した捕集 が可能であるため, 微粒子化による操作性の低下を引き起こ すことなく優れたタンパク質精製能を発揮することができる.

\section{4 結訔}

マグネタイト粒子のバイオ用途への応用を目的として，夕 ンパク質抽出精製用の磁性アミロースビーズを開発した。こ のビーズは，マルトース結合タンパク質がアミロースに特異 的に結合することを利用したものである．得られた結果は， 以下の通りである.

(1) 約 $200 \mathrm{~nm}$ の球状のマグネタイト粒子の表面に, グルコー スが直鎖状にグリコシド重合したアミロースを被着させた 磁性アミロースビーズを開発した。

(2) この磁性アミロースビーズは粒子サイズが約 $200 \mathrm{~nm}$ と小 さいにもかかわらず,大きな飽和磁化を反映して優れた磁 界捕集性を示した。 また磁界除去後の再分散性も良好で あった。

（3）大腸菌を用いてMBP (マルトース結合タンパク質)融合夕 ンパク質を発現させ, 磁性アミロースビーズを用いて精製 した結果, 非磁性レジンビーズを用いた場合に比べて約 5 倍のタンパク質精製能を示した.

(4) これは磁性アミロースビーズが微粒子で表面積が大きいた め, ビーズ表面のアミロースとマルトース結合タンパク質 との結合サイトが多くなるためと考えられた． なおこの磁性アミロースビーズは既に上市されており，夕 ンパク質抽出用ビーズとして活用されている.

\section{文献}

1) U.Hafeli, W.Schütt, J.Teller and M.Zborowski (ed.): "Scientific and Clinical Applications of Magnetic Carriers", Plenum Press, New York, (1997).

2) D.Pouliquen: "Microspheres Microcapsules \& Liposomes", ed. by R. Arshady Citus London, (2001) 495.

3) Q.A.Pankhurst, J.Connolly, S.K.Jones and J.Dobson: "Applications of magnetic nanoparticles in biomedicine", J. Phys. D: Appl. Phys., 36(2003)R167-R181

4) M.Abe and H.Handa: "Prospects for Medical Applications Using Beads in the Post-Genomic Era", J. Magn. Soc. Jpn., 28(2004) 841-846.

5) R.Boom, C.J.A.Sol, M.M.M.Salimans, C.L.Jansen, P.M.E.Wertheim-van Dillen and J.van der Noordaa: "Rapid and simple method for purification of nucleic acids", J. Clin. Microbiol., 28(1990)495-503.

6) H.Honda: "Magnetic Partcles Approaching to Biological and Medical Technology Field", J. Magn. Soc. Jpn., 25(2001)13011307.

7) M.Kitabayashi: The 21th annual meeting of the molecular biology society of Japan, Abstracts, (1998) 700. 